\title{
Perception of pathogenic or beneficial bacteria and their evasion of host immunity: pattern recognition receptors in the frontline
}

\author{
Lucie Trdá ${ }^{1,2 \dagger}$, Freddy Boutrot ${ }^{3 t}$, Justine Claverie ${ }^{1}$, Daphnée Brulé ${ }^{1}$, Stephan Dorey ${ }^{4}$ \\ and Benoit Poinssot ${ }^{1 *}$ \\ 1 Université de Bourgogne, UMR 1347 Agroécologie, Pôle Interactions Plantes Micro-organismes - ERL CNRS 6300, Dijon, \\ France, ${ }^{2}$ Laboratory of Pathological Plant Physiology, Institute of Experimental Botany, Academy of Sciences of Czech \\ Republic, Prague, Czech Republic, ${ }^{3}$ The Sainsbury Laboratory, Norwich Research Park, Norwich, UK, ${ }^{4}$ Laboratoire Stress, \\ Défenses et Reproduction des Plantes, URVVC EA 4707, Université de Reims Champagne-Ardenne, Reims, France
}

\section{OPEN ACCESS}

Edited by:

Brigitte Mauch-Mani,

Université de Neuchâtel, Switzerland

Reviewed by:

Richard Bostock

University of California, Davis, USA

Delphine Chinchilla

University of Basel, Switzerland

*Correspondence:

Benoit Poinssot

Université de Bourgogne, UMR 1347 Agroécologie INRA - uB - Agrosup,

17 rue Sully, 21000 Dijon, France benoit.poinssot@dijon.inra.fr

${ }^{t}$ These authors have contributed equally to this work.

Specialty section:

This article was submitted to Plant-Microbe Interaction,

a section of the journal

Frontiers in Plant Science

Received: 17 February 2015

Accepted: 20 March 2015

Published: 08 April 2015

Citation:

Trdá L, Boutrot F, Claverie J, Brulé $D$

Dorey S and Poinssot B (2015)

Perception of pathogenic or beneficial bacteria and their evasion of host immunity: pattern recognition receptors in the frontline.

Front. Plant Sci. 6:219.

doi: $10.3389 /$ fpls.2015.00219
Plants are continuously monitoring the presence of microorganisms to establish an adapted response. Plants commonly use pattern recognition receptors (PRRs) to perceive microbe- or pathogen-associated molecular patterns (MAMPs/PAMPs) which are microorganism molecular signatures. Located at the plant plasma membrane, the PRRs are generally receptor-like kinases (RLKs) or receptor-like proteins (RLPs). MAMP detection will lead to the establishment of a plant defense program called MAMP-triggered immunity (MTI). In this review, we overview the RLKs and RLPs that assure early recognition and control of pathogenic or beneficial bacteria. We also highlight the crucial function of PRRs during plant-microbe interactions, with a special emphasis on the receptors of the bacterial flagellin and peptidoglycan. In addition, we discuss the multiple strategies used by bacteria to evade PRR-mediated recognition.

Keywords: plant-microbe interactions, innate immunity, evasion, MAMP, PRR, flg22, FLS2, LysM

\section{Introduction}

Plants are an attractive source of nutrients and life environment for many bacteria. They are colonized by pathogenic bacteria resulting in various diseases, but also by non-pathogenic soil and epiphyte bacteria providing beneficial effects on plant growth or stress resistance. Plants form symbiosis with strictly biotrophic nitrogen-fixing Rhizobium or mutualistic interaction with plant growth-promoting rhizobacteria (PGPR) (Lugtenberg and Kamilova, 2009; Oldroyd et al., 2011). Both Rhizobium and PGPR were described to improve plant growth and enhance broad-spectrum resistance to biotic and abiotic stresses (Lugtenberg and Kamilova, 2009; Beardon et al., 2014; Pieterse et al., 2014). Pathogenic as well as beneficial bacteria are initially recognized as harmful invaders in order to limit the bacterial spread (Pel and Pieterse, 2013). This recognition is assured by an efficient plant immune system, highly similar to animal innate immunity.

At the frontline, plants possess plasma-membrane localized pattern recognition receptors (PRRs) that recognize microbe/pathogen-associated molecular patterns (MAMPs/PAMPs). These conserved signatures are part of crucial microbial structures, such as cell walls or motility organs (Boller and Felix, 2009; Newman et al., 2013). Specific PRRs also detect host-derived damageassociated molecular patterns (DAMPs), which are plant cell wall fragments or peptides produced 
as a consequence of mechanical injuries or enzymatic microbial activities (Boller and Felix, 2009; Monaghan and Zipfel, 2012; Newman et al., 2013; Savatin et al., 2014). PRR-mediated microbe sensing induces a broad variety of defense responses commonly referred to as MAMP- or PAMP-triggered immunity (MTI/PTI) (Zipfel, 2014). MTI is a defense program with complex early signaling events leading to the massive transcriptional reprogramming (Boller and Felix, 2009; Liu et al., 2014; Tsuda and Somssich, 2015) that initiates defense responses such as stomatal closure, cell wall strengthening, and production of antimicrobial compounds (Supplementary Figure S1). However, successful pathogens evolved to suppress or interfere with the MTI responses by secreting different compounds such as effectors, proteases or toxins, resulting in facilitated host colonization (Jones and Dangl, 2006). In an ongoing arms-race between the host and attacking microorganism, plants evolved host-specific intracellular receptor $(\mathrm{R})$ proteins to detect the presence or activities of effectors and to initiate a defense program in the so-called effector-triggered immunity (ETI) (Jones and Dangl, 2006; Cui et al., 2014; Wu et al., 2014).

In this review, we summarize our current knowledge on PRRsmediated recognition of bacteria, the importance of this crucial monitoring step in the context of plant disease and establishment of beneficial interaction. We also address the question of PRR evolution and the species-specific recognitions. The main focus is on the perception of the extensively-studied MAMPs flagellin and peptidoglycan.

\section{PRRs: A Highly Diverse Family of Receptors}

Plant PRRs are plasma membrane-localized receptor-like kinases (RLKs) or receptor-like proteins (RLPs) with an extracellular domain for MAMP recognition. The transmembrane RLKs contain a cytosolic serine/threonine kinase domain, while RLPs can be either glycosylphosphatidylinositol (GPI)-anchored or transmembrane proteins lacking a kinase domain. The extracellular domains of RLKs and RLPs, which confer ligand specificities, are organized into subfamilies according to domain composition (Shiu and Bleecker, 2001). While lysine motifs (LysM) or lectin motifs are common ectodomains in RLKs and RLPs, the leucine-rich repeat (LRR) extracellular motif are the most represented in plants like Arabidopsis and rice (Shiu et al., 2004), tomato (Sakamoto et al., 2012), or soybean (Liu et al., 2015). LRR domains are widespread among living organisms where they provide a structural framework for protein-protein interactions (Ng et al., 2011). In plants, LRR containing proteins are most often associated to signal transduction and immunity, and several studies have revealed their specific binding to proteinaceous microbial ligands (Boller and Felix, 2009; Monaghan and Zipfel, 2012).

The LRR-RLK FLAGELLIN-SENSITIVE 2 (FLS2) is among the best characterized plant PRRs. FLS2 detects bacterial invasion by recognition and direct binding of flagellin via its flg22 epitope (Gomez-Gomez and Boller, 2000; Chinchilla et al., 2006; Sun et al., 2013). FLS2 orthologs are found in other plant species including tomato (Robatzek et al., 2007), rice (Takai et al., 2008), or grapevine (Trdá et al., 2014). Other PRRs involved in the monitoring of bacteria include the LRR-RLK ELONGATION FACTOR-TU (EF-Tu) RECEPTOR (EFR), which perceives bacterial EF-Tu and its peptide epitope elf18 (Zipfel et al., 2006), and LysM-containing RLKs and RLPs, which mediate the recognition of $\mathrm{N}$-acetylglucosamine (GlcNAc)-containing ligands present on microbial surface, such as bacterial peptidoglycans (PGNs) but also fungal chitin (Gust et al., 2012). Chitin-related PRR system is well-studied in both dicots and monocots. Chitin hepta- or octamers are recognized by the LysM-RLK CHITIN ELICITOR RECEPTOR KINASE 1 (CERK1) and LYSIN MOTIF-CONTAINING RECEPTOR-LIKE KINASE5 (LYK5) in Arabidopsis thaliana (Miya et al., 2007; Wan et al., 2008; Petutschnig et al., 2010; Liu et al., 2012b; Cao et al., 2014) and by the complex OsCERK1/CHITIN ELICITORBINDING PROTEIN (CEBiP) in rice (Kaku et al., 2006; Miya et al., 2007; Shimizu et al., 2010). PGN perception involves CERK1 and LysM-RLPs, in Arabidopsis and rice (Willmann et al., 2011; Ao et al., 2014).

Among other identified PRRs are several LRR-RLPs, like the tomato LeEix1 and LeEix2, which bind fungal-derived ethyleneinducing xylanases (Ron and Avni, 2004), the tomato receptor Ve1, which recognizes the protein Ave1 from Verticillium fungi (de Jonge et al., 2012), the Arabidopsis AtRLP1/ReMAX, which detects a proteinaceous MAMP from Xanthomonas (Jehle et al., 2013), the Arabidopsis AtRLP30 detecting the proteinaceous elicitor SCLEROTINIA CULTURE FILTRATE ELICITOR1 (SCFE1) purified from the axenic culture filtrate of Sclerotinia sclerotiorum (Zhang et al., 2013), and RESPONSIVENESS TO BOTRYTIS POLYGALACTURONASE 1 (RBPG1/AtRLP42), which recognizes fungal endopolygalacturonases from Botrytis cinerea or Aspergillus niger (Zhang et al., 2014).

Following activation, PRRs are recruited to molecular complexes where they initiate downstream signaling. Functionality of many RLK- or RLP-PRRs then depends on heterodimerization with regulatory RLKs which improve ligand recognition and control intracellular signaling through autophosphorylation or transphosphorylation events (Monaghan and Zipfel, 2012; Böhm et al., 2014; Han et al., 2014). BRASSINOSTEROID INSENSITIVE 1 (BRI1)-ASSOCIATED KINASE 1 (BAK1)/SOMATIC EMBRYOGENESIS RECEPTOR-LIKE KINASE 3 (SERK3) is one of the key regulatory RLK assuring signaling for several RLKPRRs including FLS2 (Chinchilla et al., 2007; Heese et al., 2007; Sun et al., 2013), and EFR (Roux et al., 2011). BAK1 and its homologs are also required for the functionality of RLP-PRRs such as Ve1 (Fradin et al., 2009), LeEixl (Bar et al., 2010), and RLP30 (Zhang et al., 2013). Many LRR-RLPs also interact with SUPPRESSOR OF BIR1-1 (SOBIR1) which seems to function as an universal adaptor for different receptors (Liebrand et al., 2013; Zhang et al., 2013; Gust and Felix, 2014). Similarly, the LysM-RLK CERK1 appears to have regulatory functions for others RLKs such as LYK5 to control chitin perception in Arabidopsis (Cao et al., 2014), or for RLPs such as CEBiP to sense chitin in rice (Shimizu et al., 2010) or LYSM DOMAIN GPI-ANCHORED PROTEIN1 and 3 (LYM1 and LYM3) to control PGN recognition in Arabidopsis (Willmann et al., 2011). 


\section{PRRs at a Frontline During the Interactions with Bacteria}

Upon interaction with bacteria, plants activate immune system following the detection of a variety of MAMPs like flagellin, EF$\mathrm{Tu}, \mathrm{PGN}$, or lipopolysaccharides (LPS) (Boller and Felix, 2009) (Supplementary Figure S1). Different works highlight the relevance of the PRR-mediated MTI in plant disease resistance against bacteria. Firstly, the exogenous applications of bacteriaderived MAMPs (Wiesel et al., 2014; Burketová et al., 2015) or living bacteria (Manikandan and Raguchander, 2014) can enhance plant resistance against bacterial diseases. Secondly, studies using knock-out or silenced mutant plants for given PRRs reveal their contribution in the context of plant bacterial disease (Table 1). Loss-of-function approaches are mainly studied in Arabidopsis upon infection with Pseudomonas syringae (notably the pathovar tomato (Pto) DC3000), a foliar pathogen of tomato that also infects Arabidopsis. Gain-of-function analyses also reveal that PRR transfer is able to confer resistance. The expression of AtEFR in Nicotiana benthamiana, tomato or rice plants results in increased resistance to P. syringae pv. tabaci (Pta), tumorigenic Agrobacterium tumefaciens, Ralstonia solanacearum and Xanthomonas oryzae pv. oryzae (Xoo) after binding with elf18 epitope (Zipfel et al., 2006; Lacombe et al., 2010; Lu et al., 2015). Similarly the AtEFR transfer in wheat results in enhanced resistance against the cereal bacterial pathogen Pseudomonas syringae pv. oryzae demonstrating that PRRs can also be successfully transferred from dicot to monocot species (Schoonbeek et al., 2015). While every microbe will expose several MAMPs to host, many of these MAMPs induce comparable signaling events that converge to a common defense response (Wan et al., 2008; Boller and Felix, 2009). Nevertheless, several MAMP/PRR pairs are individually contributing to bacterial resistance (Table 1), indicating a potential quantitative contributions of certain MAMPs or an absence of redundancy in eliciting activities.

\section{Involvement of the Flagellin/FLS2 Perception System in Plant-Bacteria Interaction}

Upon P. syringae infection, the FLS2-mediated sensing of flagellin is important to restrict the bacterial invasion both in Arabidopsis (Zipfel et al., 2004; Zhang et al., 2007; Xiang et al., 2008; Zeng and He, 2010) and in N. benthamiana (Hann and Rathjen, 2007). Pretreatment with the immunogenic flagellinderived flg22 epitope induce MTI (Figure 1) and trigger protection against virulent pathogens such as Pto in Arabidopsis (Zipfel et al., 2004). Flagellin perception results in stomatal closure during the initial stage of invasion through stomata (Zeng and $\mathrm{He}$, 2010). The highest expression of FLS2 maps to tissues vulnerable for bacterial entry, such as stomata, hydathodes, and lateral roots (Beck et al., 2014) and is also correlated with the limitation of Pto colonization (Vetter et al., 2012). Accordingly, the enhanced susceptibility of the $f l s 2$ mutant toward Pto is observed when plants are infected by inoculum spray or dipping, but not with apoplastinfiltrated inoculum, suggesting that flagellin perception restricts bacterial invasion at an early step but does not play a major role in post-entry defenses (Zipfel et al., 2004; Zeng and He, 2010). However, in the root system, the intensity of the immune responses does not always correlate with the expression level of the FLS2 receptor, but rather depends on the expressing tissue (Wyrsch et al., 2015).

Flagellin from Xanthomonas campestris pv. campestris (Xcc), an important vascular pathogen of Brassicaceae, elicits MTI in Arabidopsis in a strain-specific way. Pretreatment with Xccderived flagellin also restricts $X c c$ infection of Arabidopsis plants (Sun et al., 2006). However, the flagellin immunogenicity did not limit the growth of virulent isogenic Xcc strain in Arabidopsis leaves, suggesting that $X c c$ evades or interferes with PRR-mediated immunity (Sun et al., 2006).

FLS2 can also detect flagellins of beneficial microbes to initiate plant defense responses, though to our knowledge the mechanisms, which allow these bacteria to colonize plants, are still limited. For instance, the flagellin from the PGPR Pseudomonas fluorescens (WCS374 and WCS417), and Pseudomonas putida (WCS358 and KT2440) induces some innate immune responses in tobacco cells or maize plants (van Loon et al., 2008; Planchamp et al., 2014). Flagellin and flg22 from the endophytic PGPR Burkholderia phytofirmans PsJN trigger MTI in an FLS2dependent manner in Arabidopsis and to a lesser extent in grapevine (Trdá et al., 2014). Bacillus-induced stomatal closure is abolished in the Arabidopsis fls2 mutant plant, supporting that flagellin perception also contributes to this rhizobacteriamediated defense response (Kumar et al., 2012), and further supporting the biological function of flagellin perception in roots (Millet et al., 2010; Beck et al., 2014; Wyrsch et al., 2015). Flg22triggered defense delays nodule organogenesis in the early symbiotic establishment between Lotus japonicus and Sinorhizobium meliloti (Lopez-Gomez et al., 2012). However, no effect of flg22 is observed once the symbiosis is established, probably because of secreted MTI-suppressing factors (Lopez-Gomez et al., 2012; Zamioudis and Pieterse, 2012). Interestingly, the LjFLS2 expression is down-regulated in nodules (Lopez-Gomez et al., 2012), even though the flagellin of $S$. meliloti is not immunogenic.

\section{Involvement of the LysM Perception Systems in Plant-Bacteria Interaction}

PGN is another MAMP present in bacterial cell walls. PGN consists of heteropolymeric chains of $N$-acetylglucosamine (GlcNAc) and $N$-acetylmuramic acid (MurNAc) crosslinked with a short peptide. PGN is structurally related to chitin and plant symbiontsecreted lipochitooligosaccharides. The perception of PGN from both Gram-positive and Gram-negative bacteria in Arabidopsis requires two LysM-RLPs, AtLYM1 and AtLYM3, which specifically bind PGN, and the LysM-RLK CERK1 (Gimenez-Ibanez et al., 2009; Willmann et al., 2011). The PGN sensing system is similar in rice, involving the LysM-RLK, OsCERK1, and OsLYP4 and OsLYP6, the LYM1 and LYM3 homologs (Liu et al., 2012a; Ao et al., 2014; Kouzai et al., 2014). The PGN-sensing PRRs are involved in the bacterial resistance, as the lym 1 and lym 3 mutants, insensitive to PGN, exhibit hypersusceptibility to infection with virulent Pto (Willmann et al., 2011). The silencing of OsLYP4 or OsLYP6 also leads to compromised resistance to the bacterial blight of rice caused by X. oryzae (Liu et al., 2012a). Loss of AtCERK1 results in increased susceptibility to bacterial infection caused by Pto DC3000 in Arabidopsis (Gimenez-Ibanez et al., 
TABLE 1 | RLKs and RLPs involved in basal resistance against bacteria.

\begin{tabular}{|c|c|c|c|c|c|}
\hline RLK/RLP & Family & Plant & MAMP & Bacteria & References \\
\hline \multicolumn{6}{|c|}{ PATHOGENIC BACTERIA } \\
\hline \multirow[t]{6}{*}{ FLS2 } & LRR-RLK & A. thaliana & Flagellin & Pto DC3000 & $\begin{array}{l}\text { Zipfel et al., 2004; Xiang et al., } \\
2008\end{array}$ \\
\hline & & & & Psp RW60 & de Torres et al., 2006 \\
\hline & & & & $\begin{array}{l}\text { Pto DC3000, Pto DC3000 COR-, Pto DC3000 } \\
\Delta \text { AvrPto/ } \triangle \text { AvrPtoB, Pta } 6605\end{array}$ & Nekrasov et al., 2009 \\
\hline & & & & Pta 6605, Psg race4, Pto T1 & Ishiga et al., 2011 \\
\hline & & & & $\begin{array}{l}\text { Pto DC3000, Pto DC3000 hrcC-, Pto DC3000 } \\
\text { SHopU1 }\end{array}$ & Nicaise et al., 2013 \\
\hline & & N. benthamiana & & Pta, Pto T1, Pto DC3000, Pto DC3000 hrcC- & Hann and Rathjen, 2007 \\
\hline \multirow[t]{2}{*}{ EFR } & LRR-RLK & A. thaliana & EF-Tu & Agrobacterium tumefaciens & Zipfel et al., 2006 \\
\hline & & & & Pto DC3000 $\triangle$ AvrPto/ $\Delta$ AvrPtoB & Nekrasov et al., 2009 \\
\hline $\mathrm{XA} 21^{\mathrm{a}}$ & LRR-RLK & O. sativa & & Xoo PX061 & Zhao et al., 2009 \\
\hline BAK1/SERK3 & LRR-RLK & A. thaliana & & Pto DC3000, Pto DC3000 hrcC-, Pta 6605 & Roux et al., 2011 \\
\hline NbSERK3 & LRR-RLK & N. benthamiana & & Pto DC3000, Pto DC3000 hrcC-, Pta 6605 & Heese et al., 2007 \\
\hline OsSERK2 & LRR-RLK & O. sativa & & Xoo PXO99AZ & Chen et al., 2014b \\
\hline IOS1 & LRR-RLK & A. thaliana & & Pto DC3000, Psm ES4326 & Chen et al., 2014a \\
\hline $\mathrm{BIR} 2^{\mathrm{b}}$ & LRR-RLK & A. thaliana & & Pto DC3000 & Halter et al., 2014 \\
\hline LIK $1^{b}$ & LRR-RLK & A. thaliana & & Pto DC3000 & Le et al., 2014 \\
\hline \multirow[t]{2}{*}{ PSKR $1^{b}$} & LRR-RLK & A. thaliana & PSK & A. tumefaciens C58 nocc & Loivamäki et al., 2010 \\
\hline & & & & Pto DC3000 & Mosher et al., 2013 \\
\hline RLP30 & LRR-RLP & A. thaliana & SCFE1 & Psp 1448A & $\begin{array}{l}\text { Wang et al., 2008; Zhang et al., } \\
2013\end{array}$ \\
\hline CERK1 & LysM-RLK & A. thaliana & GlcNAc & $\begin{array}{l}\text { Pto DC3000, Pto DC3000 hrcC-, Pto DC3000 } \\
\triangle \text { AvrPtoB }\end{array}$ & $\begin{array}{l}\text { Gimenez-lbanez et al., 2009; } \\
\text { Willmann et al., 2011; Wan } \\
\text { et al., } 2012\end{array}$ \\
\hline Bti9, SILyk13 & LysM-RLK & S. Iycopersicum & & 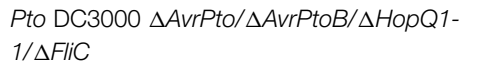 & Zeng et al., 2012 \\
\hline LYK1 & LysM-RLP & A. thaliana & & Pto DC3000, Pto DC3000 hrcC- & Wan et al., 2012 \\
\hline LYK3 ${ }^{b}$ & LysM-RLP & A. thaliana & & Pcc DSMZ 30169 & Paparella et al., 2014 \\
\hline LYK4 & LysM-RLP & A. thaliana & & Pto DC3000 & Wan et al., 2012 \\
\hline LYM1 & LysM-RLP & A. thaliana & PGN & Pto DC3000 & Willmann et al., 2011 \\
\hline LYM3 & LysM-RLP & A. thaliana & PGN & $\begin{array}{l}\text { Pto DC3000, Pto DC3000 hrcC-, Pto DC3000 } \\
\Delta \text { AvrPto/ } \triangle \text { AvrPtoB }\end{array}$ & Willmann et al., 2011 \\
\hline LYP4, LYP6 & LysM-RLP & O. sativa & & Xoc GDx, Xoo GD4 & Liu et al., 2012a \\
\hline LORE & G-Lec-RLK & A. thaliana & LPS & Pto DC3000 & Ranf et al., 2015 \\
\hline CaMBL1 & G-Lec-RLP & C. annuum & & $X_{c v}$ Ds1, Xcv Bv5-4a & Hwang and Hwang, 2011 \\
\hline $\begin{array}{l}\text { LecRK-IV.4, } \\
\text { LecRK-S.1, } \\
\text { LecRK-S.4 }\end{array}$ & L-Lec-RLK & A. thaliana & & Pto DC3000 & Wang et al., 2014 \\
\hline LecRK-V.5 & L-Lec-RLK & A. thaliana & & Pto DC3000, Pcc WPP14 & $\begin{array}{l}\text { Arnaud et al., 2012; } \\
\text { Desclos-Theveniau et al., } 2012\end{array}$ \\
\hline LecRK-VI.2 & L-Lec-RLK & A. thaliana & & Pto DC3000, Pto DC3000 COR-, Pcc SCC1 & Singh et al., 2012 \\
\hline $\mathrm{CRK} 13^{\mathrm{a}}$ & DUF26-RLK & A. thaliana & & Pto DC3000 & Acharya et al., 2007 \\
\hline $\mathrm{CRK} 2 \mathrm{O}^{\mathrm{b}}$ & DUF26-RLK & A. thaliana & & Pto DC3000 & Ederli et al., 2011 \\
\hline \multicolumn{6}{|c|}{ PLANT GROWTH-PROMOTING RHIZOBACTERIA (PGPR) } \\
\hline $\mathrm{PRK} 4^{\mathrm{b}}$ & LRR-RLK & A. thaliana & & Bacillus subtilis FB17 & Lakshmanan et al., 2013 \\
\hline WAK $3^{\mathrm{b}}$ & WAK-RLK & A. thaliana & & B. subtilis FB17 & Lakshmanan et al., 2013 \\
\hline \multicolumn{6}{|c|}{ SYMBIOTIC BACTERIA } \\
\hline NFR1 & LysM-RLK & L. japonicus & Nod factor & Mesorhizobium loti & Radutoiu et al., 2003 \\
\hline NFR5 & LysM-RLK & L. japonicus & Nod factor & M. loti & Madsen et al., 2003 \\
\hline SYMRK & LysM-RLK & L. japonicus & & M. loti & Stracke et al., 2002 \\
\hline
\end{tabular}


TABLE 1 | Continued

\begin{tabular}{|c|c|c|c|c|c|}
\hline RLK/RLP & Family & Plant & MAMP & Bacteria & References \\
\hline LYK3 & LysM-RLK & M. truncatula & & Sinorhizobium meliloti GMI5622 & Limpens et al., 2003 \\
\hline NFP & LysM-RLK & M. truncatula & Nod factor & S. meliloti GMI5622, S. meliloti SM2011 & Arrighi et al., 2006 \\
\hline DMI2/NORK & LysM-RLK & M. truncatula & & S. meliloti, S. meliloti GMI5622 & $\begin{array}{l}\text { Endre et al., 2002; Limpens et al., } \\
2005\end{array}$ \\
\hline PaNFP & LysM-RLK & P. andersonii & Nod factor & Sinorhizobium sp. NGR234 & Op den Camp et al., 2011 \\
\hline
\end{tabular}

a Determined only by gain-of-function analysis.

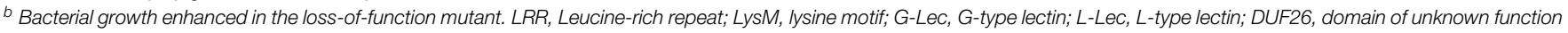
26; WAK, wall-associated kinase.

Pcc, Pectobacterium carotovorum subsp. carotovorum; Psg, Pseudomonas syringae pv. glycinea; Psm, Pseudomonas syringae pv. maculicola; Psp, Pseudomonas syringae pv. phaseolicola; Pta, Pseudomonas syringae pv. tabaci; Pto, Pseudomonas syringae pv. tomato; Xcv, Xanthomonas campestris pv. vesicatoria; Xoc, X. oryzae pv. oryzicola; Xoo, X. oryzae pv. oryzae.

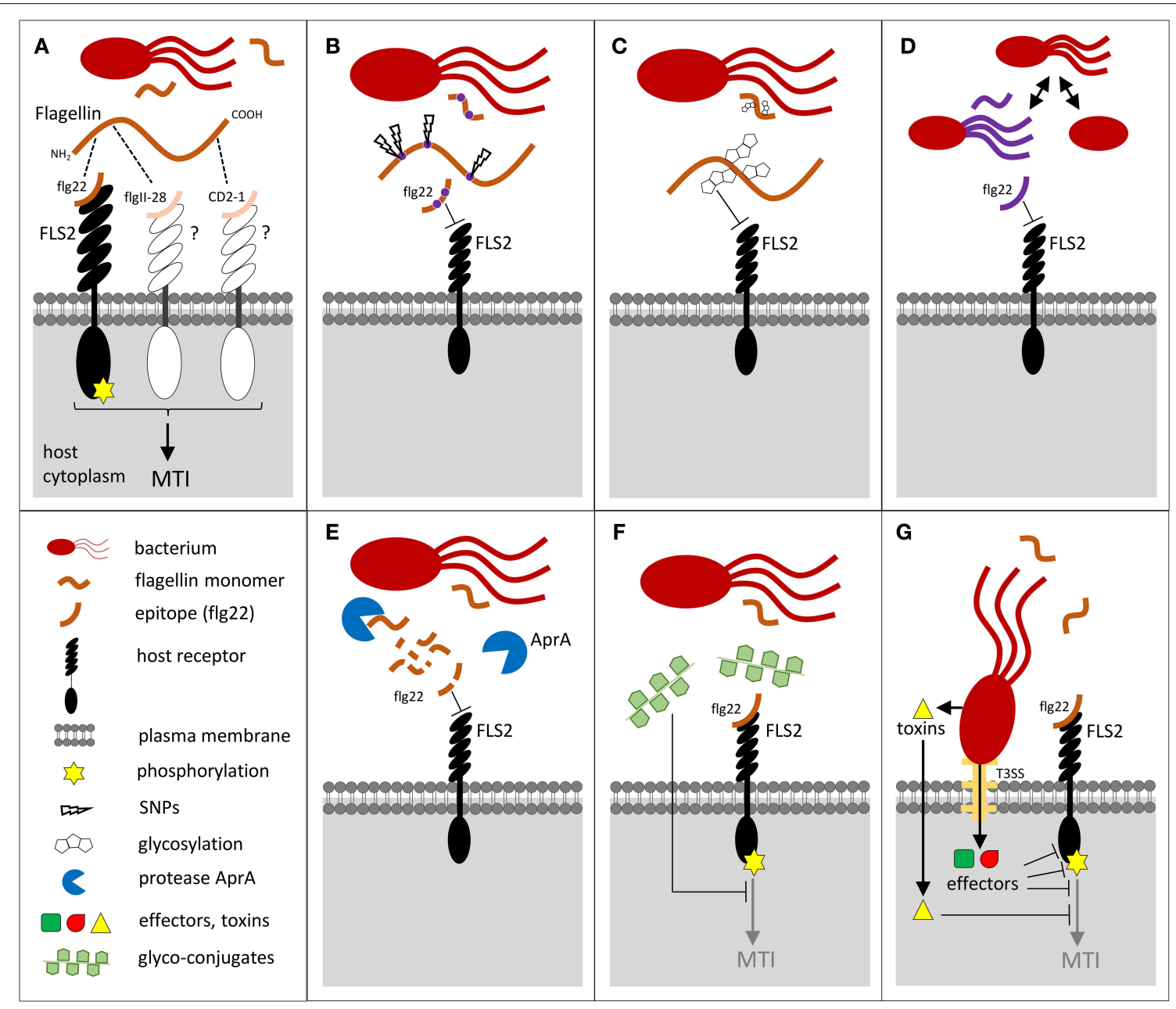

FIGURE 1 | Potential bacterial strategies employed to evade flagellin recognition via FLS2 upon bacterial invasion in plant tissues. (A) Flagellin monomers are recognized by FLS2 via the flg22 epitope, or possibly by other putative receptors detecting the epitopes flgll-28 in Solanaceae and CD2-1 in rice. The ligand binding triggers receptor kinase phosphorylation and activates defense responses leading to MAMP-triggered immunity (MTI). (B-G) Evasion strategies that hamper FLS2 recognition: (B) SNPs within the gene encoding the flagellin epitopes, (C) flagellin post-translational modifications such as glycosylation, (D) several bacterial pathogens are aflagellated, loose flagellin upon colonization, or express alternative flagellins, (E) alkaline protease AprA degrades flagellin. (F) Flagellin-mediated MTI is also inhibited by glyco-conjugates such as extracellular polysaccharides or cyclic glucan via yet poorly understood mechanisms, or (G) by bacterial effectors injected to plant cell by Type-III secretion system (T3SS), or by toxins. 
2009). Currently, the role of OsCERK1 in disease resistance is not clear. Remarkably, the components of GlcNAc sensing are independent from the flagellin sensing system requiring LRR-RLK complexes (Böhm et al., 2014).

LysM-containing PRR-like proteins are also implicated in the detection of rhizobia. Upon interaction, rhizobia secrete lipochitooligosaccharidic nodulation (Nod) factors (NFs). The structure of rhizobial Nod factors varies according to the strain and determines the host specificity (Radutoiu et al., 2007). In L. japonicus, the LysM-RLKs NF RECEPTOR 1 (LjNFR1) and LjNFR5 (Broghammer et al., 2012) recognize and directly bind NFs. Their homologs mediate NF sensing in other legumes such as MtNFP (Arrighi et al., 2006) and MtLYK3 (Limpens et al., 2003; Smit et al., 2007) in Medicago truncatula, or PsSym 37 and PsSym10 in Pisum sativum (Gust et al., 2012). NF recognition is crucial for the establishment of symbiosis between a host plant and rhizobia (Geurts et al., 2005; Liu et al., 2007; Van Wees et al., 2008; Pieterse et al., 2014). Even though Arabidopsis does not form symbioses, it recognizes Nod factors via the LysM-RLK AtLYK3 (Liang et al., 2013). This recognition results in a strong suppression of flg22induced immune responses and resistance to Pto (Liang et al., 2013). Interestingly, MtNFP, together with another LysM-RLK, MtLYR3, also seems to be involved in the perception of Myc factors, which are symbiosis-mediating signals in the arbuscular mycorrhiza (Maillet et al., 2011; Czaja et al., 2012; Fliegmann et al., 2013). Therefore, it seems that plants use overlapping systems to detect fungal and bacterial stimuli in both pathogenic and beneficial interactions.

\section{The Evasion of PRR-Mediated Immunity by Bacteria: Evolution of MAMPs as a Crucial Process}

In animals, $\varepsilon$-proteobacteria, including the important pathogens Helicobacter pylori or Campylobacter jejuni, evades the TOLLLIKE RECEPTOR 5 (TLR5) flagellin recognition system by mutating their entire flagellin recognition site (Andersen-Nissen et al., 2005; Broz and Monack, 2013). In plants, the immunogenic epitopes elf18 and flg22 also diversified among different bacteria species and strains (Sun et al., 2006; Cai et al., 2011), and with a higher rate than the non-immunogenic protein parts (McCann et al., 2012). For pathogens such as Xcc, which are coevolving with Brassicaceae, strains presenting a single amino acid polymorphism in flg22 can completely abolish the Xcc flagellin eliciting activity in Arabidopsis (Sun et al., 2006) (Figure 1B). Similar results were recently observed in rice, where $X$. oryzae pv. oryzae (Xoo) and pv. oryzicola (Xoc) evade rice FLS2 recognition with flg22 site mutations (Wang et al., 2015). The flg22 epitopes derived from A. tumefaciens, S. meliloti, and R. solanacearum are highly divergent and also escape recognition by Arabidopsis or tomato (Felix et al., 1999; Bauer et al., 2001; Pfund et al., 2004) and the flagellin of S. meliloti is not recognized in the host legume L. japonicus (Lopez-Gomez et al., 2012). It was suggested that alteration in the flg22 sequence of the PGPR B. phytofirmans might be a successful adaptation of this bacteria to avoid recognition by VvFLS2 in the grapevine host (Trdá et al., 2014). Several studies have also demonstrated that perception of a same flg22 peptide varies quantitatively in different plant species and ecotypes (Albert et al., 2010; Vetter et al., 2012; Veluchamy et al., 2014). Overall, these differences in responsiveness could reflect FLS2 co-evolution driving the detection of flagellin alleles of ecologically relevant microbial strains.

While mutations within the flg22 epitope can lead to complete MTI evasion, an additional flgII-28 epitope has recently been identified within the flagellin protein of Pto isolates. This epitope is active in Solanaceae but not in Arabidopsis, and is also under a strong selective pressure (Cai et al., 2011; Clarke et al., 2013) (Figure 1A). Over the last 30 years, the ancestral flgII-28 allele almost completely disappeared from the worldwide population of Pto and was replaced by a novel variant with reduced capacity to elicit a plant defense response (Cai et al., 2011). Surprisingly, an eliciting activity has also recently been discovered in CD2-1, a third region in the flagellin protein from the rice avirulent Acidovorax avenae (Katsuragi et al., 2015). Plant detection of the many flagellin epitopes appears to rely on different perception systems, including the potential FLS3 receptor (Clarke et al., 2013). At least two of these flagellin perception systems appear to co-exist in rice (Katsuragi et al., 2015), where they would maximize the plant defense strategy and reduce the chance of MAMP evasion. An additional eliciting region has also been identified in the EFa50 domain of the EF-Tu bacterial protein (Furukawa et al., 2014). While the EF-Tu-derived elf18 peptide is only perceived in Brassicaceae species, the recently identified EFa50 domain is fully active in rice and extends the possibility of EF-Tu recognition.

To avoid MTI recognition, bacteria use additional strategies to site mutation of active epitopes. For example, MAMPs can be masked by post-translational modifications, such as flagellin glycosylation (Hirai et al., 2011) (Figure 1C). Pta possesses pathovar-specific post-translational modifications to prevent the hypersensitive response (HR)-inducing activity of flagellin in tobacco (Taguchi et al., 2003). Flagellin glycosylation seems ubiquitous for different bacteria (Ichinose et al., 2013) and is required for the virulence of Pta, $P$. syringae pv. glycinea, $P$. aeruginosa and $X c c$ on their plant hosts (Taguchi et al., 2003, 2006; Takeuchi et al., 2003; Ichinose et al., 2013) or on a murine model (Arora et al., 2005). To reduce the amount of immunogenic epitopes, bacteria can also regulate their flagellin biosynthesis, express multiple flagellin types, shed or completely lack flagella (Hatterman and Ries, 1989; Ramos et al., 2004) (Figure 1D). The deletion in the flagellar gene cluster is observed in Xanthomonas fuscans pv. fuscans which is not motile but remains pathogenic on bean (Darrasse et al., 2013). The modulation of flagellum content, depending on the stage of root colonization, was reported in bacteria like Pseudomonas brassicacearum (Achouak et al., 2004). Several bacteria even secrete the alkaline proteases AprA, which specifically degrade flagellin monomers, spilled during the flagella construction or damage, into inactive peptides (Bardoel et al., 2011; Pel et al., 2014) (Figure 1E). Such strategy hampers the recognition by both TLR5 and FLS2 (Bardoel et al., 2011). The AprA-mediated MTI evasion seems to be widespread among bacteria species, including the beneficial ones, and leads to enhanced bacterial virulence on both plants (Pel et al., 2014) and animals (Howe and Iglewski, 1984; Liehl et al., 2006). Bacterial strategies 
to perturb MTI during symbiosis or pathogenesis also rely on secretion of glyco-conjugates, such as cyclic glucan or extracellular polysaccharides (Silipo et al., 2010) (Figure 1F). Finally, the delivery of bacterial toxins (like coronatine or syringolin) or effectors inside the plant host cell is an effective strategy to control MTI (Boller and Felix, 2009). Bacterial effectors have been shown to target de novo PRR biogenesis or directly affect the stability and activity of PRRs and their co-receptors (reviewed in Macho and Zipfel, 2014) (Figure 1G).

\section{Conclusion}

Although many studies show that PRRs are key for plant immunity, not all of the PRRs studied so far seem to contribute similarly to plant resistance. Upon plant-pathogen interactions, the importance of a given PRR depends on its level of expression, the abundance of its cognate MAMP, the rapidity and efficiency

\section{References}

Acharya, B. R., Raina, S., Maqbool, S. B., Jagadeeswaran, G., Mosher, S. L., Appel, H. M., et al. (2007). Overexpression of CRK13, an Arabidopsis cysteine-rich receptor-like kinase, results in enhanced resistance to Pseudomonas syringae. Plant J. 50, 488-499. doi: 10.1111/j.1365-313X.2007.03064.X

Achouak, W., Conrod, S., Cohen, V., and Heulin, T. (2004). Phenotypic variation of Pseudomonas brassicacearum as a plant root-colonization strategy. Mol. Plant Microbe Interact. 17, 872-879. doi: 10.1094/MPMI.2004.17.8.872

Albert, M., Jehle, A. K., Lipschis, M., Mueller, K., Zeng, Y., and Felix, G. (2010). Regulation of cell behaviour by plant receptor kinases: pattern recognition receptors as prototypical models. Eur. J. Cell Biol. 89, 200-207. doi: 10.1016/j.ejcb.2009.11.015

Andersen-Nissen, E., Smith, K. D., Strobe, K. L., Barrett, S. L., Cookson, B. T., Logan, S. M., et al. (2005). Evasion of Toll-like receptor 5 by flagellated bacteria. Proc. Natl. Acad. Sci. U.S.A. 102, 9247-9252. doi: 10.1073/pnas.0502040102

Ao, Y., Li, Z., Feng, D., Xiong, F., Liu, J., Li, J. F., et al. (2014). OsCERK1 and OsRLCK176 play important roles in peptidoglycan and chitin signaling in rice innate immunity. Plant J. 80, 1072-1084. doi: 10.1111/tpj.12710

Arnaud, D., Desclos-Theveniau, M., and Zimmerli, L. (2012). Disease resistance to Pectobacterium carotovorum is negatively modulated by the Arabidopsis Lectin Receptor Kinase LecRK-V.5. Plant Signal. Behav. 7, 1070-1072. doi: $10.4161 / \mathrm{psb} .21013$

Arora, S. K., Neely, A. N., Blair, B., Lory, S., and Ramphal, R. (2005). Role of motility and flagellin glycosylation in the pathogenesis of Pseudomonas aeruginosa burn wound infections. Infect. Immun. 73, 4395-4398. doi: 10.1128/IAI.73.7.4395-4398.2005

Arrighi, J. F., Barre, A., Ben Amor, B., Bersoult, A., Soriano, L. C., Mirabella, R., et al. (2006). The Medicago truncatula lysin motif-receptor-like kinase gene family includes NFP and new nodule-expressed genes. Plant Physiol. 142, 265-279. doi: 10.1104/pp.106.084657

Bar, M., Sharfman, M., Ron, M., and Avni, A. (2010). BAK1 is required for the attenuation of ethylene-inducing xylanase (Eix)-induced defense responses by the decoy receptor LeEix1. Plant J. 63, 791-800. doi: 10.1111/j.1365313X.2010.04282.x

Bardoel, B., van der Ent, S., Pel, M., Tommassen, J., Pieterse, C., van Kessel, K., et al. (2011). Pseudomonas evades immune recognition of flagellin in both mammals and plants. PLoS Pathog. 7:e1002206. doi: 10.1371/journal.ppat.1002206

Bauer, Z., Gomez-Gomez, L., Boller, T., and Felix, G. (2001). Sensitivity of different ecotypes and mutants of Arabidopsis thaliana toward the bacterial elicitor flagellin correlates with the presence of receptor-binding sites. J. Biol. Chem. 276, 45669-45676. doi: 10.1074/jbc.M102390200

Beardon, E., Scholes, J., and Ton, J. (2014). "How do beneficial microbes induce systemic resistance?" in Induced Resistance for Plant Defense: A of the immune activation after ligand binding and last, but not least, on the set of pathogen strategies to bypass that given PRR sensing system.

\section{Acknowledgments}

This work was financially supported by the ANR Plant KBBE project PATRIC (Grant ANR-13-KBBE-0001-01; BP, $\mathrm{DB})$ and by the Conseil Régional de Bourgogne and Bureau Interprofessionnel des Vins de Bourgogne (Grant AGRALE 12-2010-9201AAO048S02730; LT).

\section{Supplementary Material}

The Supplementary Material for this article can be found online at: http://www.frontiersin.org/journal/10.3389/fpls.2015. $00219 /$ abstract
Sustainable Approach to Crop Protection, eds R. D. Walters, A. C. Newton, D. L. Gary (Chichester: John Wiley and Sons, Ltd.), 232-248. doi: 10.1002/9781118371848.ch11

Beck, M., Wyrsch, I., Strutt, J., Wimalasekera, R., Webb, A., Boller, T., et al. (2014). Expression patterns of flagellin sensing 2 map to bacterial entry sites in plant shoots and roots. J. Exp. Bot. 65, 6487-6498. doi: 10.1093/jxb/eru366

Böhm, H., Albert, I., Fan, L., Reinhard, A., and Nürnberger, T. (2014). Immune receptor complexes at the plant cell surface. Curr. Opin. Plant Biol. 20, 47-54. doi: 10.1016/j.pbi.2014.04.007

Boller, T., and Felix, G. (2009). A renaissance of elicitors: perception of microbe-associated molecular patterns and danger signals by pattern-recognition receptors. Ann. Rev. Plant Biol. 60, 379-406. doi: 10.1146/annurev.arplant.57.032905.105346

Broghammer, A., Krusell, L., Blaise, M., Sauer, J., Sullivan, J. T., Maolanon, N., et al. (2012). Legume receptors perceive the rhizobial lipochitin oligosaccharide signal molecules by direct binding. Proc. Natl. Acad. Sci. U.S.A. 109, 13859-13864. doi: 10.1073/pnas.1205171109

Broz, P., and Monack, D. M. (2013). Newly described pattern recognition receptors team up against intracellular pathogens. Nat. Rev. Immunol. 13, 551-565. doi: 10.1038/nri3479

Burketová, L., Trdá, L., Ott, P., and Valentová, O. (2015). Bio-based resistance inducers for sustainable plant protection against pathogens. Biotechnol. Adv. doi: 10.1016/j.biotechadv.2015.01.004. [Epub ahead of print].

Cai, R., Lewis, J., Yan, S., Liu, H., Clarke, C. R., Campanile, F., et al. (2011) The plant pathogen Pseudomonas syringae pv. tomato is genetically monomorphic and under strong selection to evade tomato immunity. PLoS Pathog. 7:e1002130. doi: 10.1371/journal.ppat.1002130

Cao, Y., Liang, Y., Tanaka, K., Nguyen, C. T., Jedrzejczak, R. P., Joachimiak, A., et al. (2014). The kinase LYK5 is a major chitin receptor in Arabidopsis and forms a chitin-induced complex with related kinase CERK1. Elife 3:e03766. doi: 10.7554/eLife.03766

Chen, C. W., Panzeri, D., Yeh, Y. H., Kadota, Y., Huang, P. Y., Tao, C. N., et al. (2014a). The Arabidopsis malectin-like leucine-rich repeat receptor-like kinase IOS1 associates with the pattern recognition receptors FLS2 and EFR and is critical for priming of pattern-triggered immunity. Plant Cell 26, 3201-3219. doi: $10.1105 /$ tpc.114.125682

Chen, X., Zuo, S., Schwessinger, B., Chern, M., Canlas, P. E., Ruan, D., et al. (2014b). An XA21-associated kinase (OsSERK2) regulates immunity mediated by the XA21 and XA3 immune receptors. Mol. Plant 7, 874-892. doi: $10.1093 / \mathrm{mp} / \mathrm{ssu} 003$

Chinchilla, D., Bauer, Z., Regenass, M., Boller, T., and Felix, G. (2006). The Arabidopsis receptor kinase FLS2 binds flg22 and determines the specificity of flagellin perception. Plant Cell 18, 465-476. doi: 10.1105/tpc.105. 036574 
Chinchilla, D., Zipfel, C., Robatzek, S., Kemmerling, B., Nürnberger, T., Jones, J. D., et al. (2007). A flagellin-induced complex of the receptor FLS2 and BAK1 initiates plant defence. Nature 448, 497-500. doi: 10.1038/nature 05999

Clarke, C. R., Chinchilla, D., Hind, S. R., Taguchi, F., Miki, R., Ichinose, Y., et al. (2013). Allelic variation in two distinct Pseudomonas syringae flagellin epitopes modulates the strength of plant immune responses but not bacterial motility. New Phytol. 200, 847-860. doi: 10.1111/nph.12408

Cui, H., Tsuda, K., and Parker, J. E. (2014). Effector-triggered immunity: from pathogen perception to robust defense. Annu. Rev. Plant Biol. doi: 10.1146/annurev-arplant-050213-040012. [Epub ahead of print].

Czaja, L. F., Hogekamp, C., Lamm, P., Maillet, F., Martinez, E. A., Samain, E., et al. (2012). Transcriptional responses toward diffusible signals from symbiotic microbes reveal MtNFP- and MtDMI3-dependent reprogramming of host gene expression by arbuscular mycorrhizal fungal lipochitooligosaccharides. Plant Physiol. 159, 1671-1685. doi: 10.1104/pp.112.195990

Darrasse, A., Carrère, S., Barbe, V., Boureau, T., Arrieta-Ortiz, M. L., Bonneau, S., et al. (2013). Genome sequence of Xanthomonas fuscans subsp. fuscans strain 4834-R reveals that flagellar motility is not a general feature of xanthomonads. BMC Genomics 14:761. doi: 10.1186/1471-2164-14-761

de Jonge, R., van Esse, H. P., Maruthachalam, K., Bolton, M. D., Santhanam, P., Saber, M. K., et al. (2012). Tomato immune receptor Vel recognizes effector of multiple fungal pathogens uncovered by genome and RNA sequencing. Proc. Natl. Acad. Sci. U.S.A. 109, 5110-5115. doi: 10.1073/pnas.1119623109

Desclos-Theveniau, M., Arnaud, D., Huang, T. Y., Lin, G. J., Chen, W. Y., Lin, Y. C., et al. (2012). The Arabidopsis lectin receptor kinase LecRK-V.5 represses stomatal immunity induced by Pseudomonas syringae pv. tomato DC3000. PLoS Pathog. 8:e1002513. doi: 10.1371/journal.ppat.1002513

de Torres, M., Mansfield, J. W., Grabov, N., Brown, I. R., Ammouneh, H., Tsiamis, G., et al. (2006). Pseudomonas syringae effector AvrPtoB suppresses basal defence in Arabidopsis. Plant J. 47, 368-382. doi: 10.1111/j.1365313X.2006.02798.x

Ederli, L., Madeo, L., Calderini, O., Gehring, C., Moretti, C., Buonaurio, R., et al. (2011). The Arabidopsis thaliana cysteine-rich receptor-like kinase CRK20 modulates host responses to Pseudomonas syringae pv. tomato DC3000 infection. J. Plant Physiol. 168, 1784-1794. doi: 10.1016/j.jplph.2011. 05.018

Endre, G., Kereszt, A., Kevei, Z., Mihacea, S., Kaló, P., and Kiss, G. B. (2002). A receptor kinase gene regulating symbiotic nodule development. Nature 417, 962-966. doi: 10.1038/nature00842

Felix, G., Duran, J. D., Volko, S., and Boller, T. (1999). Plants have a sensitive perception system for the most conserved domain of bacterial flagellin. Plant J. 18, 265-276. doi: 10.1046/j.1365-313X.1999.00265.x

Fliegmann, J., Canova, S., Lachaud, C., Uhlenbroich, S., Gasciolli, V., Pichereaux, C., et al. (2013). Lipo-chitooligosaccharidic symbiotic signals are recognized by LysM receptor-like kinase LYR3 in the legume Medicago truncatula. ACS Chem. Biol. 8, 1900-1906. doi: 10.1021/cb400369u

Fradin, E. F., Zhang, Z., Juarez Ayala, J. C., Castroverde, C. D., Nazar, R. N., Robb, J., et al. (2009). Genetic dissection of Verticillium wilt resistance mediated by tomato Ve1. Plant Physiol. 150, 320-332. doi: 10.1104/pp.109.136762

Furukawa, T., Inagaki, H., Takai, R., Hirai, H., and Che, F. S. (2014). Two distinct EF-Tu epitopes induce immune responses in rice and Arabidopsis. Mol. Plant Microbe Interact. 27, 113-124. doi: 10.1094/MPMI-10-13-0304-R

Geurts, R., Fedorova, E., and Bisseling, T. (2005). Nod factor signaling genes and their function in the early stages of Rhizobium infection. Curr. Opin. Plant Biol. 8, 346-352. doi: 10.1016/j.pbi.2005.05.013

Gimenez-Ibanez, S., Ntoukakis, V., and Rathjen, J. P. (2009). The LysM receptor kinase CERK1 mediates bacterial perception in Arabidopsis. Plant Signal. Behav. 4, 539-541. doi: 10.4161/psb.4.6.8697

Gomez-Gomez, L., and Boller, T. (2000). FLS2: an LRR receptor-like kinase involved in the perception of the bacterial elicitor flagellin in Arabidopsis. Mol. Cell 5, 1003-1011. doi: 10.1016/S1097-2765(00)80265-8

Gust, A., and Felix, G. (2014). Receptor like proteins associate with SOBIR1-type of adaptors to form bimolecular receptor kinases. Curr. Opin. Plant Biol. 21, 104-111. doi: 10.1016/j.pbi.2014.07.007

Gust, A., Willmann, R., Desaki, Y., Grabherr, H., and Nurnberger, T. (2012). Plant LysM proteins: modules mediating symbiosis and immunity. Trends Plant Sci. 17, 495-502. doi: 10.1016/j.tplants.2012.04.003
Halter, T., Imkampe, J., Mazzotta, S., Wierzba, M., Postel, S., Bücherl, et al. (2014). The Leucine-rich repeat receptor kinase BIR2 is a negative regulator of BAK1 in plant immunity. Curr. Biol. 24, 134-143. doi: 10.1016/j.cub.2013.11.047

Han, Z., Sun, Y., and Chai, J. (2014). Structural insight into the activation of plant receptor kinases. Curr. Opin. Plant Biol. 20, 55-63. doi: 10.1016/j.pbi.2014.04.008

Hann, D., and Rathjen, J. (2007). Early events in the pathogenicity of Pseudomonas syringae on Nicotiana benthamiana. Plant J. 49, 607-618. doi: 10.1111/j.1365313X.2006.02981.x

Hatterman, D. R., and Ries, S. M. (1989). Motility of Pseudomonas syringae pv. glycinea and its role in infection. Phytopathology 79, 284-289. doi: 10.1094/Phyto-79-284

Heese, A., Hann, D. R., Gimenez-Ibanez, S., Jones, A. M., He, K., Li, J., et al. (2007). The receptor-like kinase SERK3/BAK1 is a central regulator of innate immunity in plants. Proc. Natl. Acad. Sci. U.S.A. 104, 12217-12222. doi: 10.1073/pnas.0705306104

Hirai, H., Takai, R., Iwano, M., Nakai, M., Kondo, M., Takayama, S., et al. (2011). Glycosylation regulates specific induction of rice immune responses by acidovorax avenae flagellin. J. Biol. Chem. 286, 25519-25530. doi: 10.1074/jbc.M111.254029

Howe, T. R., and Iglewski, B. H. (1984). Isolation and characterization of alkaline protease-deficient mutants of Pseudomonas aeruginosa in vitro and in a mouse eye model. Infect. Immun. 43, 1058-1063.

Hwang, I. S., and Hwang, B. K. (2011). The pepper mannose-binding lectin gene CaMBL1 is required to regulate cell death and defense responses to microbial pathogens. Plant Physiol. 155, 447-463. doi: 10.1104/pp.110.164848

Ichinose, Y., Taguchi, F., Yamamoto, M., Ohnishi-Kameyama, M., Atsumi, T., Iwaki, M., et al. (2013). Flagellin glycosylation is ubiquitous in a broad range of phytopathogenic bacteria. J. Gen. Plant Pathol. 79, 359-365. doi: 10.1007/s10327-013-0464-4

Ishiga, Y., Ishiga, T., Uppalapati, S. R., and Mysore, K. S. (2011). Arabidopsis seedling flood-inoculation technique: a rapid and reliable assay for studying plant-bacterial interactions. Plant Methods 7:32. doi: 10.1186/1746-4811-7-32

Jehle, A. K., Lipschis, M., Albert, M., Fallahzadeh-Mamaghani, V., Fürst, U., Mueller, K., et al. (2013). The receptor-like protein ReMAX of Arabidopsis detects the microbe-associated molecular pattern eMax from Xanthomonas. Plant Cell 25, 2330-2340. doi: 10.1105/tpc.113.110833

Jones, J. D. G., and Dangl, J. L. (2006). The plant immune system. Nature 444 323-329. doi: 10.1038/nature05286

Kaku, H., Nishizawa, Y., Ishii-Minami, N., Akimoto-Tomiyama, C., Dohmae, N. Takio, K., et al. (2006). Plant cells recognize chitin fragments for defense signaling through a plasma membrane receptor. Proc. Natl. Acad. Sci. U.S.A. 103, 11086-11091. doi: 10.1073/pnas.0508882103

Katsuragi, Y., Takai, R., Furukawa, T., Hirai, H., Morimoto, T., Katayama, T., et al. (2015). CD2-1, the C-terminal region of flagellin, modulates the induction of immune responses in rice. Mol. Plant Microbe Interact. doi: 10.1094/MPMI-1114-0372-R. [Epub ahead of print].

Kouzai, Y., Mochizuki, S., Nakajima, K., Desaki, Y., Hayafune, M., Miyazaki, H., et al. (2014). Targeted gene disruption of OsCERK1 reveals its indispensable role in chitin perception and involvement in the peptidoglycan response and immunity in rice. Mol. Plant Microbe Interact. 27, 975-982. doi: 10.1094/MPMI-03-14-0068-R

Kumar, A. S., Lakshmanan, V., Caplan, J. L., Powell, D., Czymmek, K. J., Levia, D. F., et al. (2012). Rhizobacteria Bacillus subtilis restricts foliar pathogen entry through stomata. Plant J. 72, 694-706. doi: 10.1111/j.1365-313X.2012. 05116.x

Lacombe, S., Rougon-Cardoso, A., Sherwood, E., Peeters, N., Dahlbeck, D., van Esse, H. P., et al. (2010). Interfamily transfer of a plant pattern-recognition receptor confers broad-spectrum bacterial resistance. Nat. Biotechnol. 28, 365-369. doi: 10.1038/nbt.1613

Lakshmanan, V., Castaneda, R., Rudrappa, T., and Bais, H. P. (2013). Root transcriptome analysis of Arabidopsis thaliana exposed to beneficial Bacillus subtilis FB17 rhizobacteria revealed genes for bacterial recruitment and plant defense independent of malate efflux. Planta 238, 657-668. doi: 10.1007/s00425-0131920-2

Le, M. H., Cao, Y., Zhang, X. C., and Stacey, G. (2014). LIK1, a CERK1-interacting kinase, regulates plant immune responses in Arabidopsis. PLoS ONE 9:e102245. doi: 10.1371/journal.pone. 0102245 
Liang, Y., Cao, Y., Tanaka, K., Thibivilliers, S., Wan, J., Choi, J., et al. (2013). Nonlegumes respond to rhizobial Nod factors by suppressing the innate immune response. Science 341, 1384-1387. doi: 10.1126/science.1242736

Liebrand, T. W., van den Berg, G. C., Zhang, Z., Smit, P., Cordewener, J. H., America, A. H., et al. (2013). Receptor-like kinase SOBIR1/EVR interacts with receptor-like proteins in plant immunity against fungal infection. Proc. Natl. Acad. Sci. U.S.A. 110, 10010-10015. doi: 10.1073/pnas.1220015110

Liehl, P., Blight, M., Vodovar, N., Boccard, F., and Lemaitre, B. (2006). Prevalence of local immune response against oral infection in a Drosophila/Pseudomonas infection model. PLoS Pathog. 2:e56. doi: 10.1371/journal.ppat.0020056

Limpens, E., Franken, C., Smit, P., Willemse, J., Bisseling, T., and Geurts, R. (2003). LysM domain receptor kinases regulating rhizobial Nod factor-induced infection. Science 302, 630-633. doi: 10.1126/science.1090074

Limpens, E., Mirabella, R., Fedorova, E., Franken, C., Franssen, H., Bisseling, T., et al. (2005). Formation of organelle-like N2-fixing symbiosomes in legume root nodules is controlled by DMI2. Proc. Natl. Acad. Sci. U.S.A. 102, 10375-10380. doi: 10.1073/pnas.0504284102

Liu, B., Li, J., Ao, Y., Qu, J., Li, Z., Su, J., et al. (2012a). Lysin motif-containing proteins LYP4 and LYP6 play dual roles in peptidoglycan and chitin perception in rice innate immunity. Plant Cell 24, 3406-3419. doi: 10.1105/tpc.112.102475

Liu, J., Chen, N., Grant, J. N., Cheng, Z. M., Stewart, C. N., and Hewezi, T. (2015). Soybean kinome: functional classification and gene expression patterns. J. Exp. Bot. doi: 10.1093/jxb/eru537. [Epub ahead of print].

Liu, J. Y., Maldonado-Mendoza, I., Lopez-Meyer, M., Cheung, F., Town, C. D., and Harrison, M. J. (2007). Arbuscular mycorrhizal symbiosis is accompanied by local and systemic alterations in gene expression and an increase in disease resistance in the shoots. Plant J. 50, 529-544. doi: 10.1111/j.1365313X.2007.03069.x

Liu, T., Liu, Z., Song, C., Hu, Y., Han, Z., She, J., et al. (2012b). Chitin-induced dimerization activates a plant immune receptor. Science 336, 1160-1164. doi: $10.1126 /$ science. 1218867

Liu, W., Liu, J., Triplett, L., Leach, J. E., and Wang, G. L. (2014). Novel insights into rice innate immunity against bacterial and fungal pathogens. Annu. Rev. Phytopathol. 52, 213-241. doi: 10.1146/annurev-phyto-102313-045926

Loivamäki, M., Stührwohldt, N., Deeken, R., Steffens, B., Roitsch, T., Hedrich, R., et al. (2010). A role for PSK signaling in wounding and microbial interactions in Arabidopsis. Physiol. Plant. 139, 348-357. doi: 10.1111/j.13993054.2010.01371.x

Lopez-Gomez, M., Sandal, N., Stougaard, J., and Boller, T. (2012). Interplay of flg22-induced defence responses and nodulation in Lotus japonicus. J. Exp. Bot. 63, 393-401. doi: 10.1093/jxb/err291

Lu, F., Wang, H., Wang, S., Jiang, W., Shan, C., Li, B., et al. (2015). Enhancement of innate immune system in monocot rice by transferring the dicotyledonous elongation factor Tu receptor EFR. J. Integr. Plant Biol. doi: 10.1111/jipb.12306. [Epub ahead of print].

Lugtenberg, B., and Kamilova, F. (2009). Plant-growth-promoting rhizobacteria. Annu. Rev. Microbiol. 63, 541-556. doi: 10.1146/annurev.micro.62. 081307.162918

Macho, A. P., and Zipfel, C. (2014). Targeting of plant pattern recognition receptortriggered immunity by bacterial type-III secretion system effectors. Curr. Opin. Microbiol. 23C, 14-22. doi: 10.1016/j.mib.2014.10.009

Madsen, E. B., Madsen, L. H., Radutoiu, S., Olbryt, M., Rakwalska, M., Szczyglowski, K., et al. (2003). A receptor kinase gene of the LysM type is involved in legume perception of rhizobial signals. Nature 425, 637-640. doi: 10.1038/nature02045

Maillet, F., Poinsot, V., André, O., Puech-Pagès, V., Haouy, A., Gueunier, M., et al. (2011). Fungal lipochitooligosaccharide symbiotic signals in arbuscular mycorrhiza. Nature 469, 58-63. doi: 10.1038/nature09622

Manikandan, R., and Raguchander, T. (2014). Fusarium oxysporum f. sp., lycopersici retardation through induction of defensive response in tomato plants using a liquid formulation of Pseudomonas fluorescens (Pf1). Eur. J. Plant Pathol. 140, 469-480. doi: 10.1007/s10658-014-0481-y

McCann, H. C., Nahal, H., Thakur, S., and Guttman, D. S. (2012). Identification of innate immunity elicitors using molecular signatures of natural selection. Proc. Natl. Acad. Sci. U.S.A. 109, 4215-4220. doi: 10.1073/pnas.1113893109

Millet, Y., Danna, C., Clay, N., Songnuan, W., Simon, M., Werck-Reichhart, D., et al. (2010). Innate immune responses activated in Arabidopsis roots by microbe-associated molecular patterns. Plant Cell 22, 973-990. doi: 10.1105/tpc.109.069658

Miya, A., Albert, P., Shinya, T., Desaki, Y., Ichimura, K., Shirasu, K., et al. (2007). CERK1, a LysM receptor kinase, is essential for chitin elicitor signaling in Arabidopsis. Proc. Natl. Acad. Sci. U.S.A. 104, 19613-19618. doi: 10.1073/pnas.0705147104

Monaghan, J., and Zipfel, C. (2012). Plant pattern recognition receptor complexes at the plasma membrane. Curr. Opin. Plant Biol. 15, 349-357. doi: 10.1016/j.pbi.2012.05.006

Mosher, S., Seybold, H., Rodriguez, P., Stahl, M., Davies, K. A., Dayaratne, S., et al. (2013). The tyrosine-sulfated peptide receptors PSKR1 and PSY1R modify the immunity of Arabidopsis to biotrophic and necrotrophic pathogens in an antagonistic manner. Plant J. 73, 469-482. doi: 10.1111/tpj.12050

Nekrasov, V., Li, J., Batoux, M., Roux, M., Chu, Z. H., Lacombe, S., et al. (2009). Control of the pattern-recognition receptor EFR by an ER protein complex in plant immunity. EMBO J. 28, 3428-3438. doi: 10.1038/emboj. 2009.262

Newman, M. A., Sundelin, T., Nielsen, J. T., and Erbs, G. (2013). MAMP (microbeassociated molecular pattern) triggered immunity in plants. Front. Plant Sci. 4:139. doi: 10.3389/fpls.2013.00139

Ng, A. C., Eisenberg, J. M., Heath, R. J., Huett, A., Robinson, C. M., Nau, G. J., et al. (2011). Human leucine-rich repeat proteins: a genome-wide bioinformatic categorization and functional analysis in innate immunity. Proc. Natl. Acad. Sci. U.S.A. 108(Suppl. 1), 4631-4638. doi: 10.1073/pnas.1000093107

Nicaise, V., Joe, A., Jeong, B. R., Korneli, C., Boutrot, F., Westedt, I., et al. (2013). Pseudomonas HopU1 modulates plant immune receptor levels by blocking the interaction of their mRNAs with GRP7. EMBO J. 32, 701-712. doi: 10.1038/emboj.2013.15

Oldroyd, G. E., Murray, J. D., Poole, P. S., and Downie, J. A. (2011). The rules of engagement in the legume-rhizobial symbiosis. Annu. Rev. Genet. 45, 119-144. doi: 10.1146/annurev-genet-110410-132549

Op den Camp, R., Streng, A., De Mita, S., Cao, Q., Polone, E., Liu, W., et al. (2011). LysM-type mycorrhizal receptor recruited for rhizobium symbiosis in nonlegume Parasponia. Science 331, 909-912. doi: 10.1126/science.1198181

Paparella, C., Savatin, D. V., Marti, L., De Lorenzo, G., and Ferrari, S. (2014). The Arabidopsis LYSIN MOTIF-CONTAINING RECEPTOR-LIKE KINASE3 regulates the cross talk between immunity and abscisic acid responses. Plant Physiol. 165, 262-276. doi: 10.1104/pp.113.233759

Pel, M. J., and Pieterse, C. M. (2013). Microbial recognition and evasion of host immunity. J. Exp. Bot. 64, 1237-1248. doi: 10.1093/jxb/ers262

Pel, M. J., van Dijken, A. J., Bardoel, B. W., Seidl, M. F., van der Ent, S., van Strijp, J. A., et al. (2014). Pseudomonas syringae evades host immunity by degrading flagellin monomers with alkaline protease AprA. Mol. Plant Microbe Interact. 27, 603-610. doi: 10.1094/MPMI-02-14-0032-R

Petutschnig, E., Jones, A., Serazetdinova, L., Lipka, U., and Lipka, V. (2010). The lysin motif receptor-like kinase (LysM-RLK) CERK1 is a major chitin-binding protein in Arabidopsis thaliana and subject to chitin-induced phosphorylation. J. Biol. Chem. 285, 28902-28911. doi: 10.1074/jbc.M110.116657

Pfund, C., Tans-Kersten, J., Dunning, F., Alonso, J., Ecker, J., Allen, C., et al. (2004). Flagellin is not a major defense elicitor in Ralstonia solanacearum cells or extracts applied to Arabidopsis thaliana. Mol. Plant Microbe Interact. 17, 696-706. doi: 10.1094/MPMI.2004.17.6.696

Pieterse, C. M., Zamioudis, C., Berendsen, R. L., Weller, D. M., Van Wees, S. C., and Bakker, P. A. (2014). Induced systemic resistance by beneficial microbes. Annu. Rev. Phytopathol. 52, 347-375. doi: 10.1146/annurev-phyto-082712-102340

Planchamp, C., Glauser, G., and Mauch-Mani, B. (2014). Root inoculation with Pseudomonas putida KT2440 induces transcriptional and metabolic changes and systemic resistance in maize plants. Front. Plant Sci. 5:719. doi: $10.3389 /$ fpls.2014.00719

Radutoiu, S., Madsen, L. H., Madsen, E. B., Felle, H. H., Umehara, Y., Grønlund, M., et al. (2003). Plant recognition of symbiotic bacteria requires two LysM receptor-like kinases. Nature 425, 585-592. doi: 10.1038/nature 02039

Radutoiu, S., Madsen, L. H., Madsen, E. B., Jurkiewicz, A., Fukai, E., Quistgaard, E. M., et al. (2007). LysM domains mediate lipochitin-oligosaccharide recognition and Nfr genes extend the symbiotic host range. EMBO J. 26, 3923-3935. doi: 10.1038/sj.emboj.7601826 
Ramos, H. C., Rumbo, M., and Sirard, J. C. (2004). Bacterial flagellins: mediators of pathogenicity and host immune responses in mucosa. Trends Microbiol. 12, 509-517. doi: 10.1016/j.tim.2004.09.002

Ranf, S., Gisch, N., Schäffer, M., Illig, T., Westphal, L., Knirel, Y. A., et al. (2015). A lectin S-domain receptor kinase mediates lipopolysaccharide sensing in Arabidopsis thaliana. Nat. Immunol. 16, 426-433. doi: 10.1038/ni.3124

Robatzek, S., Bittel, P., Chinchilla, D., Kochner, P., Felix, G., Shiu, S. H., et al. (2007). Molecular identification and characterization of the tomato flagellin receptor LeFLS2, an orthologue of Arabidopsis FLS2 exhibiting characteristically different perception specificities. Plant Mol. Biol. 64, 539-547. doi: 10.1007/s11103-007-9173-8

Ron, M., and Avni, A. (2004). The receptor for the fungal elicitor ethylene-inducing xylanase is a member of a resistance-like gene family in tomato. Plant Cell 16, 1604-1615. doi: 10.1105/tpc.022475

Roux, M., Schwessinger, B., Albrecht, C., Chinchilla, D., Jones, A., Holton, N., et al. (2011). The Arabidopsis leucine-rich repeat receptor-like kinases BAK1/SERK3 and BKK1/SERK4 are required for innate immunity to hemibiotrophic and biotrophic pathogens. Plant Cell 23, 2440-2455. doi: 10.1105/tpc.111.084301

Sakamoto, T., Deguchi, M., Brustolini, O. J., Santos, A. A., Silva, F. F., and Fontes, E. P. (2012). The tomato RLK superfamily: phylogeny and functional predictions about the role of the LRRII-RLK subfamily in antiviral defense. BMC Plant Biol. 12:229. doi: 10.1186/1471-2229-12-229

Savatin, D. V., Gramegna, G., Modesti, V., and Cervone, F. (2014). Wounding in the plant tissue: the defense of a dangerous passage. Front. Plant Sci. 5:470. doi: $10.3389 /$ fpls. 2014.00470

Schoonbeek, H. J., Wang, H. H., Stefanato, F. L., Craze, M., Bowden, S., Wallington, E., et al. (2015). Arabidopsis EF-Tu receptor enhances bacterial disease resistance in transgenic wheat. New Phytol. 206, 606-613. doi: 10.1111/nph.13356

Shimizu, T., Nakano, T., Takamizawa, D., Desaki, Y., Ishii-Minami, N., Nishizawa, Y., et al. (2010). Two LysM receptor molecules, CEBiP and OsCERK1, cooperatively regulate chitin elicitor signaling in rice. Plant J. 64, 204-214. doi: 10.1111/j.1365-313X.2010.04324.X

Shiu, S. H., and Bleecker, A. B. (2001). Plant receptor-like kinase gene family: diversity, function, and signaling. Sci. STKE 2001:re22. doi: 10.1126/stke.2001.113.re22

Shiu, S. H., Karlowski, W. M., Pan, R., Tzeng, Y. H., Mayer, K. F., and Li, W. H. (2004). Comparative analysis of the receptor-like kinase family in Arabidopsis and rice. Plant Cell 16, 1220-1234. doi: 10.1105/tpc.020834

Silipo, A., Erbs, G., Shinya, T., Dow, J. M., Parrilli, M., Lanzetta, R., et al. (2010). Glyco-conjugates as elicitors or suppressors of plant innate immunity. Glycobiology 20, 406-419. doi: 10.1093/glycob/cwp201

Singh, P., Kuo, Y. C., Mishra, S., Tsai, C. H., Chien, C. C., Chen, C. W., et al. (2012). The lectin receptor kinase-VI.2 is required for priming and positively regulates Arabidopsis pattern-triggered immunity. Plant Cell 24, 1256-1270. doi: 10.1105/tpc.112.095778

Smit, P., Limpens, E., Geurts, R., Fedorova, E., Dolgikh, E., Gough, C., et al. (2007). Medicago LYK3, an entry receptor in rhizobial nodulation factor signaling. Plant Physiol. 145, 183-191. doi: 10.1104/pp.107.100495

Stracke, S., Kistner, C., Yoshida, S., Mulder, L., Sato, S., Kaneko, T., et al. (2002). A plant receptor-like kinase required for both bacterial and fungal symbiosis. Nature 417, 959-962. doi: 10.1038/nature00841

Sun, W., Dunning, F., Pfund, C., Weingarten, R., and Bent, A. (2006). Withinspecies flagellin polymorphism in Xanthomonas campestris pv campestris and its impact on elicitation of Arabidopsis FLAGELLIN SENSING2-dependent defenses. Plant Cell 18, 764-779. doi: 10.1105/tpc.105.037648

Sun, Y., Li, L., Macho, A. P., Han, Z., Hu, Z., Zipfel, C., et al. (2013). Structural basis for flg22-induced activation of the Arabidopsis FLS2-BAK1 immune complex. Science 342, 624-628. doi: 10.1126/science.1243825

Taguchi, F., Shimizu, R., Inagaki, Y., Toyoda, K., Shiraishi, T., and Ichinose, Y. (2003). Post-translational modification of flagellin determines the specificity of HR induction. Plant Cell Physiol. 44, 342-349. doi: 10.1093/pcp/pcg042

Taguchi, F., Takeuchi, K., Katoh, E., Murata, K., Suzuki, T., Marutani, M., et al. (2006). Identification of glycosylation genes and glycosylated amino acids of flagellin in Pseudomonas syringae pv. tabaci. Cell. Microbiol. 8, 923-938. doi: 10.1111/j.1462-5822.2005.00674.x

Takai, R., Isogai, A., Takayama, S., and Che, F. (2008). Analysis of flagellin perception mediated by flg22 receptor OsFLS2 in rice. Mol. Plant Microbe Interact. 21, 1635-1642. doi: 10.1094/MPMI-21-12-1635
Takeuchi, K., Taguchi, F., Inagaki, Y., Toyoda, K., Shiraishi, T., and Ichinose, Y. (2003). Flagellin glycosylation island in Pseudomonas syringae pv. glycinea and its role in host specificity. J. Bacteriol. 185, 6658-6665. doi: 10.1128/JB.185.22.6658-6665.2003

Trdá, L., Fernandez, O., Boutrot, F., Héloir, M. C., Kelloniemi, J., Daire, X., et al. (2014). The grapevine flagellin receptor VvFLS2 differentially recognizes flagellin-derived epitopes from the endophytic growth-promoting bacterium Burkholderia phytofirmans and plant pathogenic bacteria. New Phytol. 201, 1371-1384. doi: 10.1111/nph.12592

Tsuda, K., and Somssich, I. E. (2015). Transcriptional networks in plant immunity. New Phytol. doi: 10.1111/nph.13286. [Epub ahead of print].

van Loon, L., Bakker, P., van der Heijdt, W., Wendehenne, D., and Pugin, A. (2008). Early responses of tobacco suspension cells to rhizobacterial elicitors of induced systemic resistance. Mol. Plant Microbe Interact. 21, 1609-1621. doi: 10.1094/MPMI-21-12-1609

Van Wees, S., Van der Ent, S., and Pieterse, C. (2008). Plant immune responses triggered by beneficial microbes. Curr. Opin. Plant Biol. 11, 443-448. doi: 10.1016/j.pbi.2008.05.005

Veluchamy, S., Hind, S. R., Dunham, D. M., Martin, G. B., and Panthee, D. R. (2014). Natural variation for responsiveness to flg22, flgII-28, and csp22 and Pseudomonas syringae pv. tomato in heirloom tomatoes. PLoS ONE 9:e106119. doi: 10.1371/journal.pone.0106119

Vetter, M., Kronholm, I., He, F., Haweker, H., Reymond, M., Bergelson, J., et al. (2012). Flagellin perception varies quantitatively in Arabidopsis thaliana and its relatives. Mol. Biol. Evol. 29, 1655-1667. doi: 10.1093/molbev/mss011

Wan, J., Tanaka, K., Zhang, X. C., Son, G. H., Brechenmacher, L., Nguyen, T. H., et al. (2012). LYK4, a lysin motif receptor-like kinase, is important for chitin signaling and plant innate immunity in Arabidopsis. Plant Physiol. 160, 396-406. doi: 10.1104/pp.112.201699

Wan, J., Zhang, X. C., Neece, D., Ramonell, K. M., Clough, S., Kim, S. Y., et al. (2008). A LysM receptor-like kinase plays a critical role in chitin signaling and fungal resistance in Arabidopsis. Plant Cell 20, 471-481. doi: $10.1105 /$ tpc.107.056754

Wang, G. D., Ellendorff, U., Kemp, B., Mansfield, J. W., Forsyth, A., Mitchell, K., et al. (2008). A genome-wide functional investigation into the roles of receptor-like proteins in Arabidopsis. Plant Physiol. 147, 503-517. doi: 10.1104/pp.108.119487

Wang, S., Sun, Z., Wang, H., Liu, L., Lu, F., Yang, J., et al. (2015). Rice OsFLS2mediated perception of bacterial flagellins is evaded by Xanthomonas oryzae pvs. oryzae and oryzicola. Mol. Plant. doi: 10.1016/j.molp.2015.01.012. [Epub ahead of print].

Wang, Y., Bouwmeester, K., Beseh, P., Shan, W., and Govers, F. (2014). Phenotypic analyses of Arabidopsis T-DNA insertion lines and expression profiling reveal that multiple L-type lectin receptor kinases are involved in plant immunity. Mol. Plant Microbe Interact. 27, 1390-1402. doi: 10.1094/MPMI-06-14-0191-R

Wiesel, L., Newton, A. C., Elliott, I., Booty, D., Gilroy, E. M., Birch, P. R., et al. (2014). Molecular effects of resistance elicitors from biological origin and their potential for crop protection. Front. Plant Sci. 5:655. doi: 10.3389/fpls.2014.00655

Willmann, R., Lajunen, H., Erbs, G., Newman, M., Kolb, D., Tsuda, K., et al. (2011) Arabidopsis lysin-motif proteins LYM1 LYM3 CERK1 mediate bacterial peptidoglycan sensing and immunity to bacterial infection. Proc. Natl. Acad. Sci. U.S.A. 108, 19824-19829. doi: 10.1073/pnas.1112862108

Wu, S., Shan, L., and He, P. (2014). Microbial signature-triggered plant defense responses and early signaling mechanisms. Plant Sci. 228, 118-126. doi: 10.1016/j.plantsci.2014.03.001

Wyrsch, I., Domínguez-Ferreras, A., Geldner, N., and Boller, T. (2015). Tissuespecific FLAGELLIN-SENSING 2 (FLS2) expression in roots restores immune responses in Arabidopsis fls2 mutants. New Phytol. 206, 774-784. doi: $10.1111 /$ nph. 13280

Xiang, T., Zong, N., Zou, Y., Wu, Y., Zhang, J., Xing, W., et al. (2008). Pseudomonas syringae effector AvrPto blocks innate immunity by targeting receptor kinases. Curr. Biol. 18, 74-80. doi: 10.1016/j.cub.2007.12.020

Zamioudis, C., and Pieterse, C. (2012). Modulation of host immunity by beneficial microbes. Mol. Plant Microbe Interact. 25, 139-150. doi: 10.1094/MPMI-0611-0179

Zeng, L., Velásquez, A. C., Munkvold, K. R., Zhang, J., and Martin, G. B. (2012). A tomato LysM receptor-like kinase promotes immunity and its kinase 
activity is inhibited by AvrPtoB. Plant J. 69, 92-103. doi: 10.1111/j.1365313X.2011.04773.x

Zeng, W., and He, S. (2010). A prominent role of the flagellin receptor FLAGELLIN-SENSING2 in mediating stomatal response to Pseudomonas syringae pv tomato DC3000 in Arabidopsis. Plant Physiol. 153, 1188-1198. doi: 10.1104/pp.110.157016

Zhang, J., Shao, F., Li, Y., Cui, H., Chen, L., Li, H., et al. (2007). A Pseudomonas syringae effector inactivates MAPKs to suppress PAMP-induced immunity in plants. Cell Host Microbe 1, 175-185. doi: 10.1016/j.chom.2007.03.006

Zhang, L., Kars, I., Essenstam, B., Liebrand, T. W., Wagemakers, L., Elberse, J., et al. (2014). Fungal endopolygalacturonases are recognized as microbe-associated molecular patterns by the arabidopsis receptor-like protein RESPONSIVENESS TO BOTRYTIS POLYGALACTURONASES1. Plant Physiol. 164, 352-364. doi: 10.1104/pp.113.230698

Zhang, W., Fraiture, M., Kolb, D., Löffelhardt, B., Desaki, Y., Boutrot, F. F., et al. (2013). Arabidopsis receptor-like protein 30 and receptor-like kinase suppressor of BIR1-1/EVERSHED mediate innate immunity to necrotrophic fungi. Plant Cell 25, 4227-4241. doi: 10.1105/tpc.113.117010

Zhao, J., Fu, J., Li, X., Xu, C., and Wang, S. (2009). Dissection of the factors affecting development-controlled and race-specific disease resistance conferred by leucine-rich repeat receptor kinase-type $\mathrm{R}$ genes in rice. Theor. Appl. Genet. 119, 231-239. doi: 10.1007/s00122-009-1032-3
Zipfel, C. (2014). Plant pattern-recognition receptors. Trends Immunol. 35, 345-351. doi: 10.1016/j.it.2014.05.004

Zipfel, C., Kunze, G., Chinchilla, D., Caniard, A., Jones, J. D. G., Boller, T., et al. (2006). Perception of the bacterial PAMP EF-Tu by the receptor EFR restricts Agrobacterium-mediated transformation. Cell 125, 749-760. doi: 10.1016/j.cell.2006.03.037

Zipfel, C., Robatzek, S., Navarro, L., Oakeley, E. J., Jones, J. D., Felix, G., et al. (2004). Bacterial disease resistance in Arabidopsis through flagellin perception. Nature 428, 764-767. doi: 10.1038/nature 02485

Conflict of Interest Statement: The authors declare that the research was conducted in the absence of any commercial or financial relationships that could be construed as a potential conflict of interest.

Copyright (๔ 2015 Trdá, Boutrot, Claverie, Brulé, Dorey and Poinssot. This is an open-access article distributed under the terms of the Creative Commons Attribution License (CC BY). The use, distribution or reproduction in other forums is permitted, provided the original author(s) or licensor are credited and that the original publication in this journal is cited, in accordance with accepted academic practice. No use, distribution or reproduction is permitted which does not comply with these terms. 